\title{
Reduced fine sediment flux and channel change in response to the managed diversion of an upland river channel
}

\author{
Matthew Thomas Perks ${ }^{1}$ and Jeff Warburton ${ }^{2}$ \\ ${ }^{1}$ Department of Geography, Politics and Sociology, Newcastle University, Newcastle, NE1 7RU, UK \\ ${ }^{2}$ Department of Geography, Durham University, Durham, DH1 3LE, UK \\ Correspondence to: Matthew Thomas Perks (matthew.perks@ncl.ac.uk)
}

Received: 7 September 2015 - Published in Earth Surf. Dynam. Discuss.: 12 October 2015

Revised: 30 June 2016 - Accepted: 3 August 2016 - Published: 2 September 2016

\begin{abstract}
This paper describes the implementation of a novel mitigation approach and subsequent adaptive management, designed to reduce the transfer of fine sediment $(<2 \mathrm{~mm})$ in Glaisdale Beck, a small, predominantly upland catchment in the UK. Hydro-meteorological and suspended sediment data sets are collected over a 2-year period spanning pre- and post-diversion periods in order to assess the impact of the channel reconfiguration scheme on the fluvial suspended sediment dynamics. Analysis of the river response demonstrates that the fluvial sediment system has become more restrictive with reduced fine sediment transfer. This is characterized by reductions in flow-weighted mean suspended sediment concentrations from $77.93 \mathrm{mg} \mathrm{L}^{-1}$ prior to mitigation, to $74.36 \mathrm{mg} \mathrm{L}^{-1}$ following the diversion. A Mann-Whitney $\mathrm{U}$ test found statistically significant differences $(p<0.001)$ between the pre- and post-monitoring median suspended sediment concentrations (SSCs). Whilst application of one-way analysis of covariance (ANCOVA) on the coefficients of sediment rating curves developed before and after the diversion found statistically significant differences $(p<0.001)$, with both $\log a$ and $b$ coefficients becoming smaller following the diversion. Non-parametric analysis indicates a reduction in residuals through time $(p<0.001)$, with the developed LOWESS model over-predicting sediment concentrations as the channel stabilizes. However, the channel is continuing to adjust to the reconfigured morphology, with evidence of a headward propagating knickpoint which has migrated $120 \mathrm{~m}$ at an exponentially decreasing rate over the last 7 years since diversion. The study demonstrates that channel reconfiguration can be effective in mitigating fine sediment flux in headwater streams but the full value of this may take many years to achieve whilst the fluvial system slowly readjusts.
\end{abstract}

1

\section{Introduction}

Changing catchment conditions and land use impact locally on river systems, through slope-channel coupling, but their cumulative impact is of global importance (Foley et al., 2005). Recent government data reveal that $61 \%$ of monitored water bodies within the less favourable areas (LFAs) of England and Wales are currently at risk of failing the Water Framework Directive (WFD; 2000/60/EC) due to poor ecological status (Environment Agency, 2015), a key determinant of which is suspended sediment (Collins and Anthony, 2008a). Such statistics have led to calls for suspended sed- iment to have a higher profile in diffuse pollution policy (e.g. Collins and McGonigle, 2008). This is assured given the pressure to ensure long-term improvements in water quality under the WFD and the government's own target of water bodies in England being in excellent health by 2050 (DEFRA, 2011). However, to ensure improvements in condition and prevent the continual degradation of many upland catchments, river systems and their diverse ecosystems, a range of measures will need to be implemented to control fine sediment transfer (Newson and Large, 2006; DEFRA, 2011; Rickson, 2014). 
Lateral erosion in particular plays an important role in channel migration, meander development and the delivery of fine sediment $(<2 \mathrm{~mm})$ to upland channels (Lawler, 1993; Lawler et al., 1997; Fuller et al., 2003). Documented contributions of bankside sediment sources range from $1.5 \%$ to over $80 \%$ of total fine sediment flux (Bull, 1997; Stott, 1997), with high magnitude episodic events transferring significant volumes of bank-eroded material (e.g. Carling, 1986). However, on a global scale, the magnitude of sediment transfer typically observed in these upland catchments is relatively low (Evans and Warburton, 2005). Changes to runoff generation processes (Marshall et al., 2009; Holden et al., 2015), and the spatial distribution and magnitude of erosion (McHugh, 2007), can however result in the enhanced conveyance of bankside and hillslope eroded material into the fluvial networks draining these catchments (Owens et al., 2005). Drivers of these changes in the uplands of the UK include the following: farming and forestry operations (Burt et al., 1983; Tilman et al., 2002); moorland burning (Imeson, 1971; Arnold-Forster, 2002; Holden et al., 2015); peat degradation; metal mining (Macklin et al., 1997); artificial drainage (Ramchunder et al., 2009); and channelization (Brown, 1997; Gilvear and Bradley, 1997), with few catchments remaining that can be described as being in reference condition (Sear et al., 2000, 2009). Enhanced sediment generation and delivery processes place additional pressure on aquatic habitats, increasing the risk of chemical and biological pollution, and habitat decline (Robinson, 1973).

The implementation of positive measures to abate the transfer of fine sediment and pollutants whilst preserving the desired physical and biological functioning is, however, extremely challenging due to the legacy of extrinsic and intrinsic, historical and contemporary controls on dynamic river systems (Schumm, 1977; Elliott, 1997; Newson, 2002). This is partly why sensitive upland rivers of the UK have attracted less direct restoration than lowland counterparts (Environment Agency, 1998); and given the difficulties of access and working conditions have not received large-scale investment in geomorphological engineering.

To ensure a positive legacy of the continuing and future management of our upland catchments, it is imperative that rehabilitation efforts are based on sound scientific knowledge acquired through the progressive development of a solid evidence base consisting of the fluvial and/or catchment response to a range of interventions across multiple scales (Brierley et al., 2010). This will allow competent authorities to (a) predict the effectiveness of control measures (e.g. Wilkinson et al., 2013); (b) predict the cost-effectiveness of resource allocation (e.g. Posthumus et al., 2013); and (c) enable reliable and transparent decisions to be made about future catchment operations (Collins et al., 2012). Comprehensive monitoring is rarely undertaken with few quantitative assessments of whether restoration results in significant improvements in river function (Newson, 2002; Skinner and
Bruce-Burgess, 2005; Newson and Large, 2006; Wohl et al., 2015).

The aim of this research conducted in the upland catchment of Glaisdale Beck; UK, is to assess the success of a novel mitigation approach and subsequent adaptive management, designed to reduce fine sediment transfer. This is assessed from a geomorphic and biotic viewpoint and is achieved by monitoring the schemes impact on the river channels form, and the suspended sediment dynamics, whilst taking into account hydro-meteorological drivers. Due to the rarity of direct modifications to upland river systems this research offers insights into the functioning of a realigned upland river system and may act as a test case, or trial for other upland catchments facing similar pressures and seeking appropriate solutions.

\section{Regional setting}

\subsection{Context and problem}

Glaisdale Beck is located in the North Yorkshire region of England, UK with a catchment area of $15.6 \mathrm{~km}^{2}$ (Fig. 1). Originating on Glaisdale Moor at an altitude of $382 \mathrm{~m}$, the upland river (as defined by Atherden, 1992) flows $7 \mathrm{~km}$ before joining the River Esk. The climate is cool, temperate, with annual average rainfall of less than $1000 \mathrm{~mm}$. The local geology is dominated by Jurassic rocks of the Whitby Mudstone Formation (mudstone and siltstone with calcareous nodule bands) overlain by unconsolidated boulder clay and undifferentiated drift in the valley bottoms (British Geological Survey, 1992). The dominant land-use is moorland, pasture and rough grazing with some woodland, particularly in the lower catchment (Fig. 1). Each of these managed landunits creates specific pressures. The presence of artificial drains (or grips) on Glaisdale Moor alter the runoff regime, and the practise of managing the dry heath may result in bare soil exposure, increasing erosion risk. On lower-lying farm land, reported stocking densities of up to 1.51 livestock units per hectare creates diffuse pollution pressures within the catchment (Emery, 2010).

The Esk is a river of both ecological and economic importance at a national scale. It is the principle river in Yorkshire for Atlantic salmon and sea trout and is one of only two rivers on the east coast of England to have known populations of the freshwater pearl mussel, Margaritifera margaritifera (Geist, 2005). This species is one of the most critically endangered bi-valves in the world; listed on Annexes II and V of the EU Habitats and Species Directive and Appendix III of the Bern Convention (Machordom et al., 2003; Skinner et al., 2003). However, siltation and excessive suspended sediment concentrations (SSCs) have been attributed to causing their decline. This has led to local conservation and restoration efforts being driven by the National Park over the last 20 years (Arnold-Forster, 2002; Emery, 2010). 


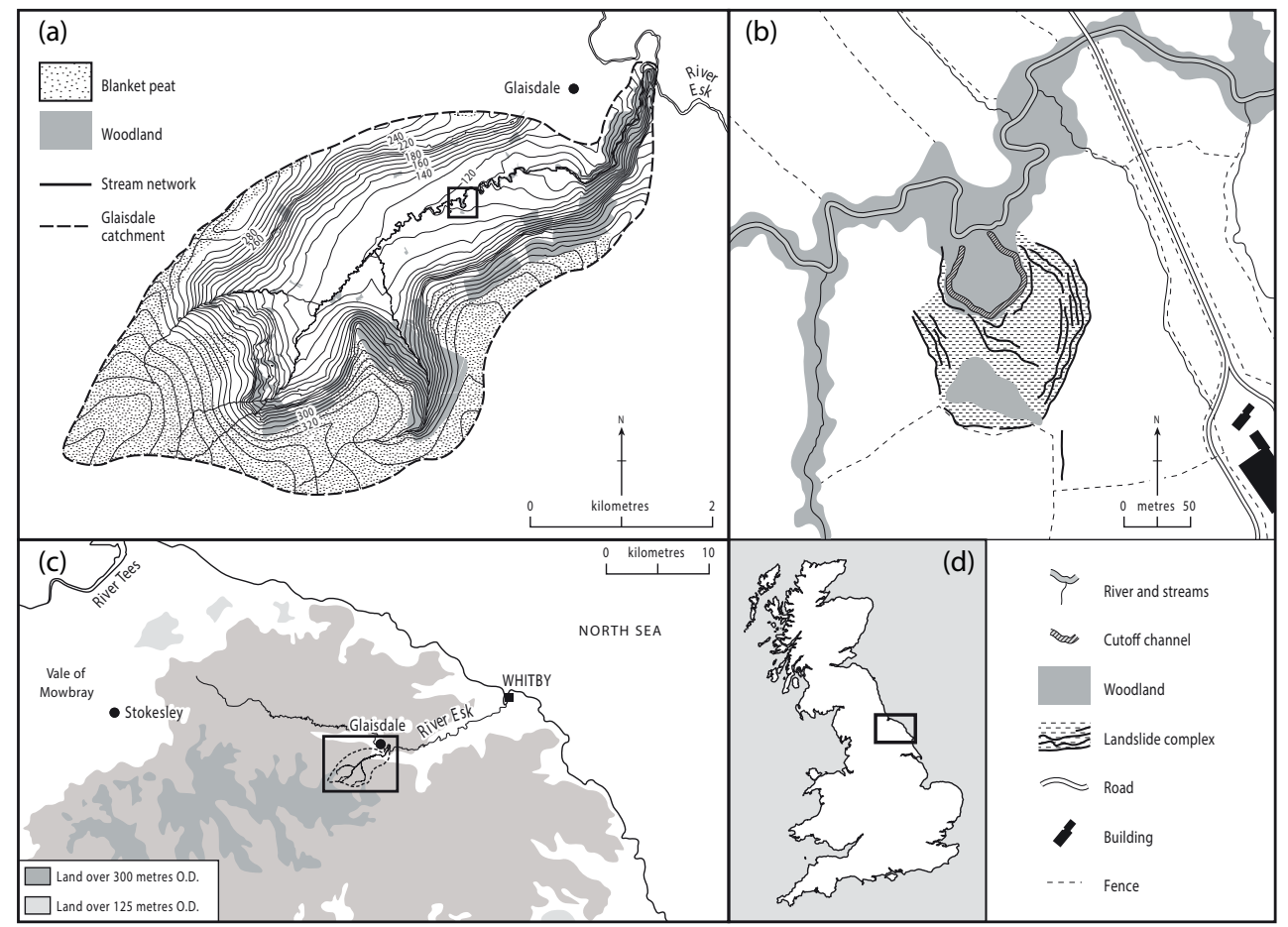

Figure 1. Maps illustrating (a) Glaisdale catchment and associated land units. Contours are displayed at $10 \mathrm{~m}$ intervals. The box identifies the reach of Glaisdale Beck experiencing extensive landslide inputs, which was subsequently diverted. This is shown in detail in (b). The location of Glaisdale Beck in the regional and national context is provided in (c) and (d) respectively. ${ }^{\odot}$ Crown Copyright/database right 2015. An Ordnance Survey/EDINA supplied service.

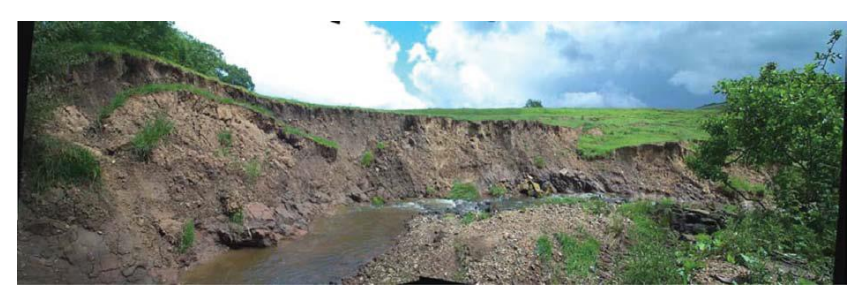

Figure 2. View looking upstream at a steep, $3 \mathrm{~m}$ high, near vertical bank of unconsolidated sediment exposed along Glaisdale Beck. This is at the distal end of a large hillslope failure complex.

Previous research has highlighted the Glaisdale subcatchment as a key contributor to fine sediment fluxes in the Esk catchment (Bracken and Warburton, 2005). Through local surveys, a critical source area of fine sediment supply to the beck was identified (Warburton, 2007). This was a section of exposed, near-vertical, $\sim 3 \mathrm{~m}$ high channel banks $\sim 100 \mathrm{~m}$ in length consisting of unconsolidated sediments and overlain by shallow surface vegetation, which is regularly accessed by livestock (Fig. 2). The availability of accessible material is also exacerbated by progressive movement of a large hillslope failure complex which supplies large quantities of easily eroded sediment directly to the river channel. Such failures are well documented in the North York Moors (Waltham and Forster, 1999). It was deemed that this com- bination of factors limited the potential for success of traditional channel margin stabilization approaches.

\subsection{Reconfiguration}

Following consultation and the presentation of available options (cf. Warburton, 2007), the competent agencies decided the most appropriate course of action was to divert the existing channel away from the toe of the large hillslope landslide, and re-establish the stream course further to the north (Fig. 3). Emery et al. (2013) provide a thorough discussion of the process involved in reaching this consensus. In October 2007, engineering work to modify the course of Glaisdale Beck commenced. Prior to the realignment, the river had a meandering channel with a sinuosity ratio of 1.56 and a local gradient of $0.0061 \mathrm{~m} \mathrm{~m}^{-1}$. By diverting the beck from its original pathway, the reach was shortened by $250 \mathrm{~m}$, increasing the local slope to $0.050 \mathrm{~m} \mathrm{~m}^{-1}$. To accommodate for the increased slope, it was recommended that a boulder revetment should be installed along the outside of the new meander, along with drop structures constructed from large $(>0.5 \mathrm{~m}$ ) boulders (Fig. 3, Drop Structure A). These measures were recommended to prevent the beck reverting to its previous configuration and the occurrence of headward erosion and renewed bank erosion by undercutting (Hey, 1996). 


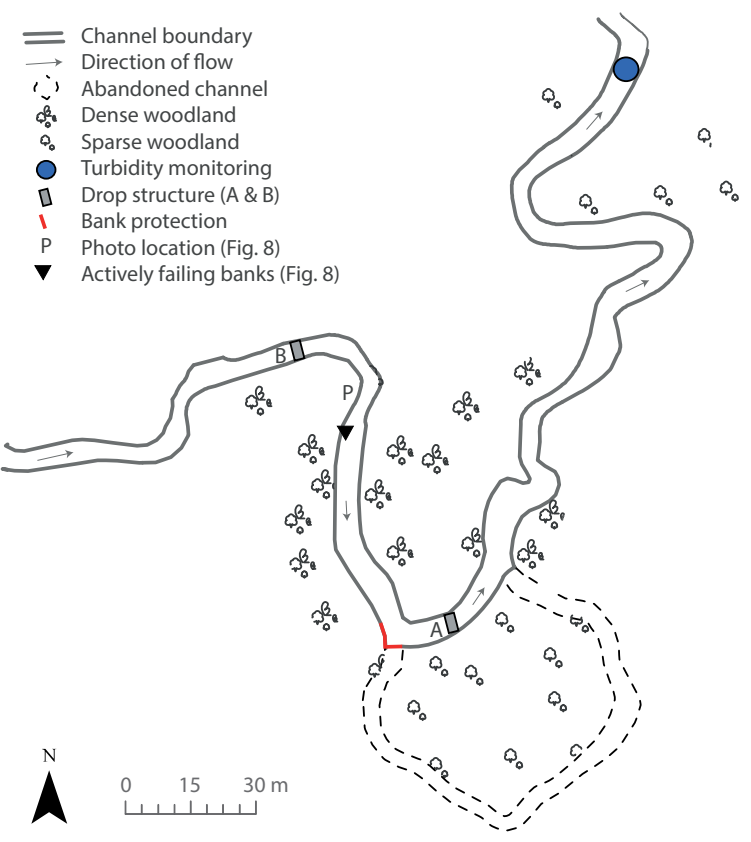

Figure 3. Map showing the diversion location with control measures and monitoring site.

Although a range of measures to control channel readjustment and fine sediment release were recommended, not all could be fully implemented due to local site conditions and the determined specification was not followed in detail. The most important deviation was the use of insufficient material to construct the drop structure located on the new cut-through section (Fig. 3, Drop structure A). As a result of this structure becoming undermined, it needed to be later reinforced along with the addition of a drop structure upstream of the diversion (Fig. 3, Drop structure B). This additional work was undertaken during February 2008. However, the materials and construction of the upstream drop-structure also deviated from the recommended specifications.

Following the establishment of the newly engineered channel, it was assumed that in the medium and long term, the disconnection of the immediately available and easily accessible sediment source from the watercourse would have demonstrable impacts on the suspended sediment load and SSCs, which would benefit the in-stream ecology and habitat quality of Glaisdale Beck. However, in the short-term following the diversion it was recognized that a temporary disequilibrium would be created, resulting in the active adjustment of the channel to the new conditions. Although previous studies have documented the immediate and instantaneous impact of such disturbances (e.g. Brookes, 1987; Sear and Archer, 1998); few provide a sustained assessment of the impacts of modification (e.g. Gilvear and Bradley, 1997).

\section{Materials and methods}

\subsection{Physical data collection}

An assessment of the fluvial sediment system of Glaisdale Beck was undertaken by monitoring the fine sediment dynamics immediately prior to and in response to the realignment work (Perks and Warburton, 2016a). An in-stream monitoring station was located $250 \mathrm{~m}$ downstream of the diversion (Fig. 3). This included a McVan Analite 395 turbidity probe and PDCR 1830 Campbell Scientific pressure transducer connected to a CR10X data-logger, alongside an ISCO 3700 automatic water sampler. Monitoring of turbidity and level began on 21st September 2007, providing 19 days of data prior to the engineering work, which took place on 10 October 2007. Monitoring continued following the diversion for 2 years. Turbidity and river level data were collected at $15 \mathrm{~min}$ intervals with discharge estimated through the combination of river stage and velocity estimates (cf. Perks et al., 2014). The turbidity probe was deployed as a surrogate for SSC (cf. Gippel, 1995). To quantify the relationship, calibrations were conducted between the formazin calibrated turbidity (FTU) generated by the turbidity probe and SSCs determined using the gravimetric technique on samples collected by an ISCO automatic sampler and discrete manual sampling. In attempting to identify post-diversion changes in fine sediment dynamics it was deemed important to account for not only impacts of flow on the fine sediment response, but also how rainfall erosivity varied temporally. This ensured that systematic changes in storm/erosion intensity as a driver of the observed sediment dynamics could be ruled out, which would not necessarily have been picked up using the flow measurements alone. The rainfall estimates for the catchment are derived from the UK's NIMROD radar network (Perks and Warburton, 2016e). This provides rainfall estimates with spatial and temporal resolutions of $1 \mathrm{~km}$ and 5 min respectively and was available for $95 \%$ of the entire monitoring period. The NIMROD radar network is one of the best operational sources of rainfall information, capable of producing rainfall estimates that are statistically similar to those derived from rain-gauges (Cranston and Black, 2006; Zhu et al., 2014). Additional $15 \mathrm{~min}$ river level data spanning 1998-2014 were acquired from the Environment Agency hydrometric monitoring station at Lealholm (NZ7627207611), located on the main Esk, approximately $3 \mathrm{~km}$ upstream of the confluence with Glaisdale Beck (Perks and Warburton, 2016f). Complimentary to the collection of continuous data, geomorphological surveys were conducted on nine occasions between October 2007 and April 2014, with changes in the local morphology being quantified using a combination of a Leica $1200+$ total station, Leica 1200 GNSS station and a Leica NA720 automatic level and staff (Perks and Warburton, 2016b, c). 


\subsection{Data treatment}

FTU - SSC pairings were plotted and a linear regression model was adopted to best describe the fit between the variables (Table 1). A condition set for the model was that the intercept had to pass through zero. Further to the development of the linear model, the uncertainty of the regression coefficients was evaluated using a bootstrap re-sampling method $(n=2000)$. The uncertainty of the regression coefficients along with the number of calibration samples $(n)$ and summary statistics is shown in Table 1 . This calibration is within the acceptable range of uncertainty for the given operating range, as set out by Gray et al. (2002).

Sediment rating curves were constructed following the log-transformation of discharge normalized by mean discharge, $\hat{Q}$ (cf. Warrick, 2015) and SSC from which the regression coefficients $a$ and $b$ were obtained by ordinary least squares linear regression:

$\operatorname{LogSSC}=\log a+b \cdot \log \hat{Q}$.

By transforming the data so that the trend is linear in logspace, the regression slope can be back-transformed into original units, producing an exponential fit (Helsel and Hirsch, 1992). The Duan (1983) smearing factor was subsequently applied to correct for bias introduced during the transformation process. This correction factor (CF) is widely used and unlike alternative approaches does not assume normality in the residuals. Following back-transformation, the rating curve is modified using Eq. (2).

$\mathrm{SSC}=a \hat{Q} b(\mathrm{CF})$

Non-parametric analysis was also undertaken to describe the relation between $\hat{Q}$ and SSC. The locally weighted scatter smoothing (LOWESS) technique was chosen as it provides an objective approach that infers the form of the relationship from the observations directly with no prior assumption (Cleveland, 1979; Hicks et al., 2000). In conducting this analysis, a "stiffness factor" was required to determine the proportion of the population to include in the weighted local regression. A range of factors were evaluated from 1 to $50 \%$ at $0.12 \%$ intervals. The span that minimized the sum of square errors for predictions generated by a leave-one-out cross validation was selected.

Following acquisition of the NIMROD rainfall data for the UK, a representative rainfall rate for the Glaisdale Beck catchment was calculated by first averaging the rainfall estimates $\left(\mathrm{mm} \mathrm{h}^{-1}\right)$ from across the catchment grid at each 5 min time step. Utilizing these data, the unit rainfall energy $e$ (MJ ha ${ }^{-1} \mathrm{~mm}^{-1}$ ) for each rainfall event $r$ is calculated from the empirical function proposed by Brown and Foster (1987):

$e_{r}=0.29\left[1-0.72 \exp \left(-0.05 i_{r}\right)\right]$,

where $i$ is the rainfall intensity during the time interval $\left(\mathrm{mm} \mathrm{h}^{-1}\right)$. The event rainfall erosivity index Ei30
( $\mathrm{MJ} \mathrm{mm} \mathrm{ha}{ }^{-1} \mathrm{~h}^{-1}$ ) is subsequently calculated as follows (Meusburger et al., 2012; Sheridan et al., 2011; AnguloMartínez et al., 2009):

$\mathrm{Ei} 30=\left(\sum_{r=1}^{0} e_{r} v_{r}\right) I_{30}$

where $v$ is the rainfall depth $(\mathrm{mm})$ and $I_{30}$ is the maximum rainfall intensity during a period of 30 min during the event $\left(\mathrm{mm} \mathrm{h}^{-1}\right)$. Finally, the median rainfall erosivity index is calculated for each season, taking account of all observed storm events.

\section{Results}

\subsection{Pre-diversion}

During the short pre-diversion monitoring period, $\hat{Q}$ and SSC were highly correlated (Kendall's Tau $=0.66$; $p<0.001)$. The flow-weighted mean concentration was $77.93 \mathrm{mg} \mathrm{L}^{-1}$ with a $\mathrm{SSC}_{50}$ of $35.19 \mathrm{mg} \mathrm{L}^{-1}$, range spanning 15.37-671.21 mg L$~^{-1}$ and median absolute deviation of $12.15 \mathrm{mg} \mathrm{L}^{-1}$. These available data indicate that prior to diversion, the river conditions were unfavourable for the freshwater pearl mussel populations due to the exceedance of a $10 \mathrm{mg} \mathrm{L}^{-1}$ critical threshold (Stutter et al., 2008), and may also be sub-optimal for salmonid and cyprinid fish populations due to SSCs at low flow exceeding $25 \mathrm{mg} \mathrm{L}^{-1}$ (Bilotta et al., 2010; Collins and Anthony, 2008a).

\subsection{Disturbance}

During channel diversion, no measures were put in place to minimize downstream transfer of fine sediment. Consequentially, the maximum observed instantaneous SSCs reached $2468 \mathrm{mg} \mathrm{L}^{-1}$, nearly $3600 \%$ greater than the upstream concentration (Fig. 4). Although this declined rapidly, concentrations were still $510 \%$ greater 2 hours after the breakthrough, with downstream concentrations of $359 \mathrm{mg} \mathrm{L}^{-1}$. Such disturbances have been observed elsewhere; with sediment loads immediately downstream of in-stream works measuring between 40 and $150 \%$ more than those immediately upstream (Brookes, 1987; Sear and Archer, 1998). The observed duration and concentrations may have short-term impacts on the primary productivity and the free-living ecology of the river such as reduced natural penetration of light; increases in the rate of drift and reduced abundance of invertebrates (Rosenberg and Wiens, 1978; Doeg and Milledge, 1991); and modified salmonid feeding and foraging behaviour (Robertson et al., 2007). However, a longer term concern was the potential for this material to clog salmonid redds, reducing oxygen availability (Carling, 1984). Positively, annual survey data indicated no decline in the numbers of salmonids the following year (Environment Agency, 2011). 
Table 1. Summary statistics of the turbidity probe field calibrations. The relationship is significant at the $99.9 \%$ level.

\begin{tabular}{lllll}
\hline & Calibration & SSC Range $\left(\mathrm{mg} \mathrm{L}^{-1}\right)$ & $R^{2}$ & Uncertainty (95\%) \\
\hline Glaisdale Beck $(n=58)$ & $y=1.1298 x$ & $1.65-1266.20$ & 0.92 & $22.96 \%$ \\
\hline
\end{tabular}

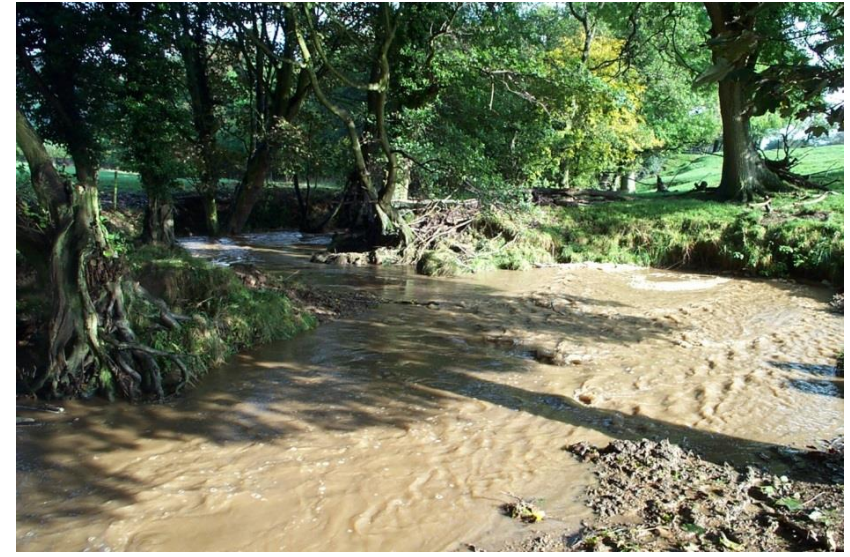

Figure 4. View looking downstream of the channel diversion during the construction phase. Photograph taken on day of diversion works; 10 October 2007.

\subsection{Impact}

During the 2 year's of flow and SSC monitoring following the diversion, $\hat{Q}$ and SSC were highly correlated (Kendall's $\mathrm{Tau}=0.36 ; p=0)$. The flow-weighted mean concentration falls by $5 \%$ to $74.36 \mathrm{mg} \mathrm{L}^{-1}$. $\mathrm{SSC}_{50}$ is $18.98 \mathrm{mg} \mathrm{L}^{-1}$, which is significantly different to the pre-diversion median SSC with a reduction following the diversion (Mann-Whitney $U$ test; $p<0.001)$. The monotonic trend in $\hat{Q}$ is positive (Kendall's Tau $=0.05 ; p<0.001$ ), whilst the SSC trend is negative (Kendall's Tau $-0.05 ; p<0.001$ ). Following diversion, median concentration falls below the $25 \mathrm{mg} \mathrm{L}^{-1}$ threshold of the (now repealed) EU Freshwater Fish Directive (2006/44/EC); however it still exceeds the $10 \mathrm{mg} \mathrm{L}^{-1}$ level recommended for the protection of freshwater pearl mussel habitats (Stutter et al., 2008). These thresholds are exceeded 33.75 and $94.11 \%$ of the time respectively.

\subsubsection{Parametric time series analysis}

Regression of $\log C$ on $\log \hat{Q}$ provides a linear model, which when back-transformed predicts SSC from discharge for the pre- and post-diversion monitoring periods (Table 2), resulting in the development of empirical models which meet the acceptance threshold for analysis utilized by Syvitiski et al. (2000). However, above a $\hat{Q}$ threshold value (Tv) of $4.6 \mathrm{~m}^{3} \mathrm{~s}^{-1}$ the suspended sediment response is poorly replicated by a power-law model; the SSC response to increasing discharge becomes dampened. This results in curva-

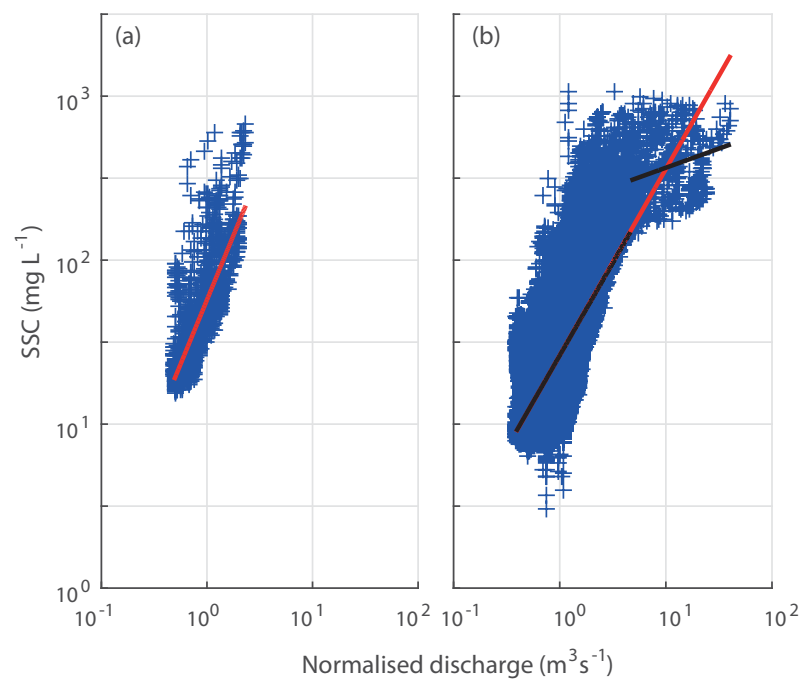

Figure 5. Relationship between normalized discharge and suspended sediment concentrations (a) before and (b) following the diversion of Glaisdale Beck. The red line represents all the available data for the time period. The broken black line represents the threshold models for normalized discharge within the range of greater than and less than $4.6 \mathrm{~m}^{3} \mathrm{~s}^{-1}$.

ture in the $\hat{Q}$-SSC relationship in log space which is inadequately characterized by the model (Fig. 5). This reduced sensitivity is demonstrated when the data set it partitioned at $\mathrm{Tv}$ and the creation of two discrete models: one for low flows and one for high flows. The resulting $b$ coefficient shifts from 1.13 (when $\hat{Q}<\mathrm{Tv}$ ) to 0.23 (when $\hat{Q}>\mathrm{Tv}$ ) (Table 2). The form, explained variance and error associated with the partitioned model (when $\hat{Q}<\mathrm{Tv}$ ) is similar to the original model incorporating all observed discharges (Table 2). However, the partitioned model (when $\hat{Q}>\mathrm{Tv}$ ) has poorly explained variance and large errors associated with it $\left(R^{2}=0.07\right.$; RMSE $\left.=174.54\right)$. This is indicative of a complex and highly variable SSC response at moderate and high discharges in Glaisdale Beck. This is related to the supplylimited nature of the fluvial sediment system which is related to either a reduction in the availability of fine sediment sources, e.g. through the exhaustion of readily available material temporarily stored on the river bed (Gao and Josefson, 2012); and/or a reduction in rainfall effectiveness as the storm progresses (Wood, 1977). These dynamics cannot be adequately characterized using a simple power law.

The observed rating curve coefficients are within the normal range of what would be expected for temperate rivers (Reid and Frostick, 1987; Syvitski et al., 2000); however fol- 
Table 2. Summary of the developed empirical models for the prediction of suspended sediment concentrations from normalized discharge. $\mathrm{Tv}$ is the normalized discharge threshold value for model partition, set at $4.6 \mathrm{~m} \mathrm{~s}^{-1}$.

\begin{tabular}{llrrrrrr}
\hline Period & Condition & $n$ & Log Model & $R^{2}$ & Final Model & $R^{2}$ & RMSE \\
\hline Before & All & 1776 & $1.7575+1.5669 x$ & 0.59 & $57.22 x^{1.57} 1.1448^{*}$ & 0.45 & 52.72 \\
After & All & 56653 & $1.4199+1.1360 x$ & 0.47 & $26.30 x^{1.14} 1.19^{*}$ & 0.35 & 48.63 \\
After & $\hat{Q}<\operatorname{Tv}$ & 56106 & $1.4188+1.1292 x$ & 0.40 & $26.23 x^{1.13} 1.1919^{*}$ & 0.38 & 36.03 \\
After & $\hat{Q}>\operatorname{Tv}$ & 547 & $2.3303+0.2332 x$ & 0.08 & $213.94 x^{0.23} 1.0961^{*}$ & 0.07 & 174.54 \\
\hline
\end{tabular}

* Represents use of the Duan (1983) correction factor.

lowing diversion, the $\log a$ coefficient decreases from 1.76 to 1.42 , whilst the $b$ exponent also decreases from 1.57 to 1.14 . These coefficients have been shown to respond to patterns of sediment production, availability and transport capacity, with reductions being associated with a move to a more restrictive sediment transport system (Warrick and Rubin, 2007; Asselman, 2000; Yang et al., 2007). To test whether these changes are statistically significant and to confirm the impacts of modification, a one-way analysis of covariance test (ANCOVA) was conducted on the log-model coefficients. For this to be a valid comparison, only discharge data within the range observed pre-diversion were utilized (i.e. normalized discharge $<2.37 \mathrm{~m}^{3} \mathrm{~s}^{-1}$ ). Results indicate highly significant differences between the pre- and post-diversion monitoring period for both $\log a$ and $b$ coefficients (Table 3). This confirms that modification of Glaisdale Beck has resulted in a suspended sediment regime which responds significantly differently to changes in flow, likely as a consequence of the changes to local shear stress and sediment availability following the diversion. Encouragingly from a river remediation point-of-view, a $\hat{Q}$ of $2.37 \mathrm{~m}^{3} \mathrm{~s}^{-1}$ prior to modification would have yielded a typical SSC value of $221.77 \mathrm{mg} \mathrm{L}^{-1}$, whereas the modified system would typically result in a SSC of $70.33 \mathrm{mg} \mathrm{L}^{-1}$; equivalent to a $68 \%$ reduction. These findings suggest differences in flow effectiveness, with flows following diversion failing to have the same erosive impact (Hicks et al., 2000; Wolman and Miller, 1960).

\subsubsection{Non-parametric time series analysis}

As a consequence of the aforementioned curvature between $\hat{Q}$ and SSCs, LOWESS analysis was undertaken to quantify the form of the relationship and to assess how this changed as a result of channel diversion. A stiffness factor of 0.134 was assigned to the model as this minimized the sum of the squared errors. The form of the LOWESS fit is largely comparable to that of the power law up to a $\hat{Q}$ of $\sim 7 \mathrm{~m}^{3} \mathrm{~s}^{-1}$ where curvature in the suspended sediment response becomes pronounced as a result of relatively lower SSCs (Fig. 6). A second inflection is identified at $20 \mathrm{~m}^{3} \mathrm{~s}^{-1}$ as a result of increasing SSCs at the higher discharge range. This non-parametric model performs better than the original power law (Table 2), with an RMSE of 39.29. The
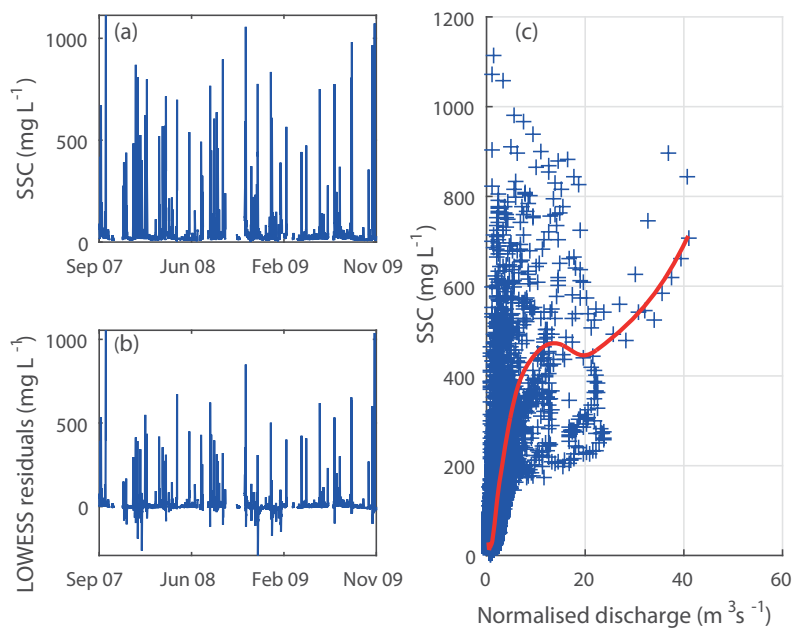

Figure 6. (a) Suspended sediment concentrations and (b) residuals over the entire monitoring period as a result of (c) the LOWESS model developed between normalized discharge and suspended sediment concentrations.

median of the residuals is $-3.62 \mathrm{~m} \mathrm{~L}^{-1}$ with the residuals exhibiting a slight negative monotonic trend over time (Kendall's Tau $=-0.04 ; p=0$ ), indicating a reduction in the observed SSCs relative to the model predictions. The correlation between $\hat{Q}$ and model residuals is also negative (Kendall's Tau $=-0.213 ; p=0$ ). This is a reflection of the heteroscedasticity in the residuals, with a wide range of SSCs observed at low flows whilst during higher magnitude events the suspended sediment response is better constrained.

The maximum positive LOWESS residuals are identified as occurring during the construction of the channel diversion $\left(+1054 \mathrm{mg} \mathrm{L}^{-1}\right)$ and as a result of SSC spikes occurring immediately prior to, and independent of storm events during November 2008 and $2009\left(+849.5\right.$ and $+1038 \mathrm{mg} \mathrm{L}^{-1}$ respectively; Fig. $6 \mathrm{~b}$ ). The maximum negative residuals occur during storm events in January and December 2008, resulting in deviations between observed and predicted concentrations of -263.5 and $-292.1 \mathrm{mg} \mathrm{L}^{-1}$ respectively. Upon the calculation of the median LOWESS residuals for each monitored storm, and by season, striking patterns are observed (Fig. 7a-b). For each storm occurring prior to di- 
Table 3. Results of $t$ tests on model parameters for the relationship between Log normalized $Q$ and Log SSC, before and after channel diversion.

\begin{tabular}{lcc|cc}
\hline & \multicolumn{2}{c|}{$\log a(T$ and $p$ values $)$} & \multicolumn{2}{c}{$b(T$ and $p$ values $)$} \\
\cline { 2 - 4 } Before vs. After & 22.72 & 0.00 & 13.21 & 0.00 \\
\hline
\end{tabular}

version, highly positive median residuals are produced as a result of the LOWESS model underestimating concentrations. During this unit of analysis (storm and base flow component), the median of the residuals is $13.86 \mathrm{mg} \mathrm{L}^{-1}$; the highest observed during the entire monitoring period. During the following three seasons (autumn 2008-spring 2009), the median of the residuals is negative with a range spanning -2.64 to $-4.63 \mathrm{mg} \mathrm{L}^{-1}$. Negative residuals are also produced for the same seasons during the second year of monitoring, although their magnitude is greater (with the exception of spring). The seasonal pattern of the residuals is quasi-cyclic with largest post-diversion residuals occurring during the summer months, followed by the spring months. However, there are no observable relationships between the erosivity index of the rainfall and the residuals produced by the LOWESS model, therefore this observed pattern is not believed to be influenced by seasonality in the storm intensity and erosion potential (Fig. 7c-d). Whilst the role of land management activities, natural variability of sediment supply across the wider catchment, and additional stressors, or mediating factors cannot be excluded, it is significant in the context of this research that the trend in the residuals is negative, with the suspended sediment response becoming increasingly dampened throughout the monitoring period.

\subsubsection{Long-term geomorphic impact}

Although direct monitoring of the hydrology and sediment dynamics at Glaisdale beck was concluded in 2009, 2 years after the channel diversion, the longer term development of the site was observed through site visits up until 2014. Over this period in the Esk catchment, the median river level was slightly less than the long-term (1998-2014) median level. However, the probability of moderate and high magnitude flow events was equal, or greater than prior to the diversion (Table 4).

As a result of these erosive events during this period, continued erosion in the form of a headward migrating knickpoint (visible as a step in the clay of the river bed substrate) has resulted in a progressive wave of channel instability that has migrated upstream. This is the morphological response to over-steepening of the channel gradient in the vicinity of the original channel diversion. Due to a lack of appropriately engineered grade control (drop) structures in the engineered reach this has resulted in channel bed lowering, bank undercutting and lateral bank failures upstream. Figure 8 shows a series of three time lapse images taken from approximately $50 \mathrm{~m}$ upstream of the head of the channel diversion reach over a 7-year period from 2007 to 2014. During this time extensive bank erosion and channel widening have occurred. At this particular site, erosion was evident only 2 weeks after the initial diversion with the knickpoint migrating through the reach, lowering the bed elevation. In response, the banks started to slump, tension cracks approximately $1.2 \mathrm{~m}$ back from the bank appeared on the bank top and the bank dropped approximately $0.4 \mathrm{~m}$ with a slight rotational movement, which over time became more pronounced (Fig. 8a). As time progressed, further slumping led to destruction of the rotated soil block allowing the river to flow behind the disintegrating bank material and erode directly the freshly exposed soil (Fig. 8b). Eventually the soil block became completely detached from the bank but was held together by a root ball of a tree growing in the centre of the failed block (Fig. 8c). This became established in the centre of the channel diverting flow around both sides of the obstruction, eventually triggering a second phase of bank collapse (Fig. 8c). However, due to increased channel width the final phase of bank collapse resulted in a soil wedge at the base of the bank which appears to have protected the toe of the bank preventing further lateral expansion. The extent of erosion shown in these images represents the "worst-case" example of erosion with the total channel width increasing by nearly $300 \%$ by 2014 .

The temporal sequence of images in Fig. 8a to $\mathrm{c}$ are also labelled on Fig. 9 to cross reference the local erosion observed at a point in relation to the progression of the eroding knickpoint upstream. Over the 7-year observation period the point of observed bank undercutting and bed instability, shown by a small step in the river bed long profile, has migrated $187 \mathrm{~m}$ upstream at an average annual rate of approximately $30 \mathrm{~m}$ per year. Over time this rate has slowed dramatically from an initial rate, in the first 2 months since diversion, of nearly $1.4 \mathrm{~m} \mathrm{day}^{-1}$ to an eventual rate of less than $1 \mathrm{~mm} \mathrm{day}^{-1}$; a decrease in rate of approximately $1400 \%$ (Fig. 9). This reduction in the rate of knickpoint migration follows an exponential trend with the rate slowing dramatically towards the present (2014). The most recent observations suggest the headward migration of the channel knickpoint has now almost ceased and there is little evidence of further bank instability much beyond $200 \mathrm{~m}$ upstream of the point of the original channel diversion. The increase in slope caused by the diversion has largely been accommodated by adjustments to the channel bed slope and cross-section morphology. It is estimated that the channel diversion increased the local reach 


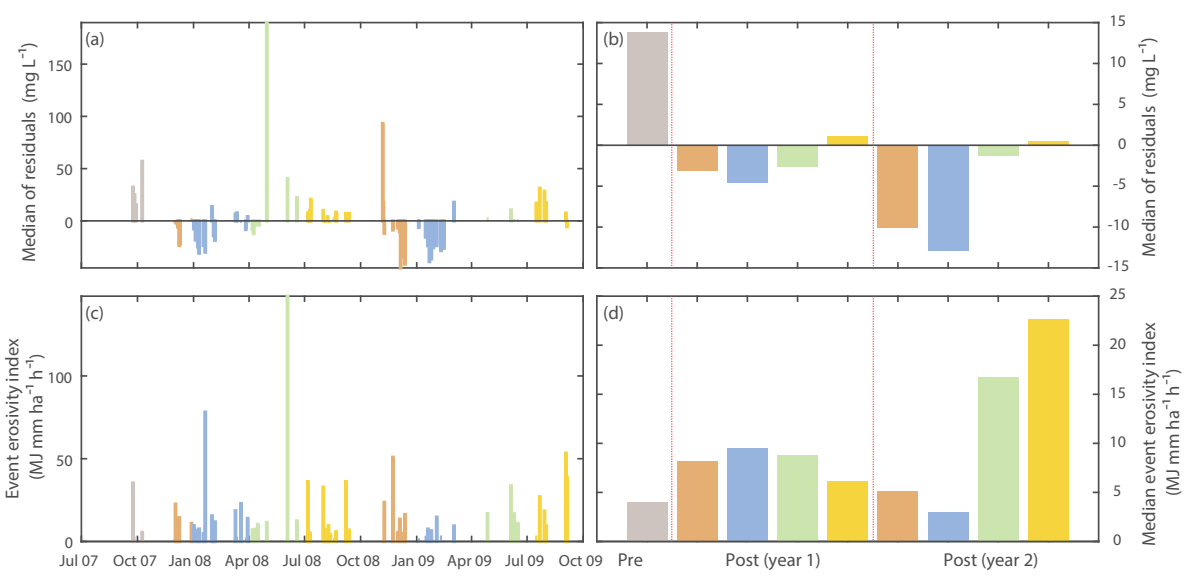

Figure 7. Median of the LOWESS model residuals grouped by (a) individual storm event and; (b) season, and the rainfall erosivity index grouped by (c) individual storm event and (d) season. The colours represent the different seasons with brown representing autumn; blue winter; green - spring and; yellow - summer.

Table 4. Summary statistics calculated from river level data collected at Lealholm monitoring station (NZ7627207611) based on observations at $15 \mathrm{~min}$ intervals. Statistics provided include the mean, median and maximum river levels and the probability that the river level exceeds the long term (1998-2014) median (M), median · 5 (M5), and median · 10 (M10) threshold values. This is calculated for both pre-diversion conditions (2 December 1998-10 October 2007) and post-diversion conditions (10 October 2007-8 April 2014).

\begin{tabular}{llll|lll}
\hline Condition & Mean & Median & Maximum & \multicolumn{3}{|c}{ Exceedance probability } \\
\cline { 2 - 7 } & $(\mathrm{m})$ & $(\mathrm{m})$ & $(\mathrm{m})$ & M & M5 & M10 \\
\hline Pre-Diversion & 0.24 & 0.19 & 3.66 & 0.53 & 0.012 & 0.0025 \\
Post-Diversion & 0.22 & 0.16 & 3.13 & 0.44 & 0.014 & 0.0025 \\
\hline
\end{tabular}

Table 5. Changes in reach averaged slopes before and after channel diversion.

\begin{tabular}{lrl}
\hline Reach/Condition & Date & $\begin{array}{l}\text { Average channel } \\
\text { slope }\left(\mathrm{m} \mathrm{m}^{-1}\right)\end{array}$ \\
\hline Meandering channel pre-diversion & $<2007$ & 0.0061 \\
Diverted - engineered channel & 2007 & 0.05 \\
Adjusted channel & 2014 & 0.0065 \\
\hline
\end{tabular}

slope from approximately 0.0061 (following the old meandering course) to 0.05 in the freshly engineered diversion reach (Table 5). Following 7 years of channel readjustment the contemporary 2014 channel slope has now returned to the pre-diversion state, which explains why further upstream knickpoint migration and erosion have largely ceased.

The thalweg profile along the reconfigured channel reach was surveyed in detail on two occasions in March 2009 and April 2014 spanning a period of 5 years. A comparison of the two channel long profiles (Fig. 10) supports the observations of the sequence of bank collapse (Fig. 8), and headward progression of the eroding knickpoint (Fig. 9). The period between March 2009 and April 2014 (500 to 2400 days since diversion) spans the period of adjustment following major channel degradation which occurred in the first 500 days following the engineering works (Fig. 9). Nevertheless the channel was still degrading over this period and some significant local variations in channel sedimentation were observed (Fig. 10). In Fig. 10, A and B represent locations of the two drop structures (weirs) and the dashed rectangle is the zone of rapid channel change associated with bank collapse shown in Fig. 8. Above the upper weir, apart from a deep scour pool below a piece of large woody debris $(\mathrm{c} .10 \mathrm{~m})$ upstream of the grade control structure, the channel has aggraded slightly over time. Downstream of the lower weir, although the level of the main bars has remained relatively consistent between 2009 and 2014, the degraded pools remain over deepened with bed levels lower by almost $0.5 \mathrm{~m}$ in places. Between these two sub-reaches is the dynamic reach affected by the large-scale bank collapses (Fig. 8); here local adjustments in bed level dominate with erosion and deposition varying by up to $\pm 0.5 \mathrm{~m}$ although the overall pattern is net degradation of the reach. The dynamic response of these three sub-reaches to the channel reconfiguration characterizes nicely the ongoing adjustment of the stream. Above the upper weir the channel is largely stable with net aggradation; in the areas of bank collapses local adjustments continue; and below the lower weir the channel still shows signs of bed lowering. 

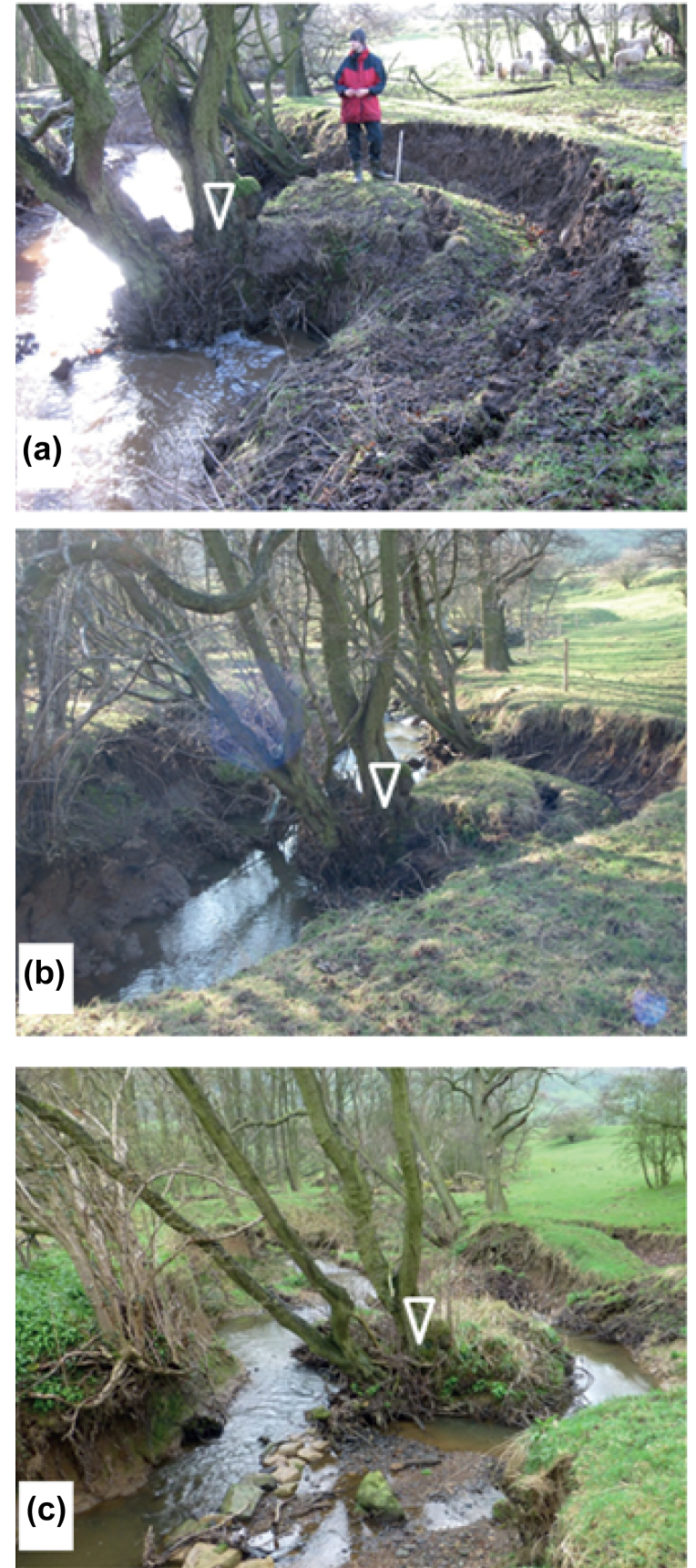

Figure 8. Time lapse sequence of a right river bank collapse approximately $50 \mathrm{~m}$ upstream of channel diversion. Images show the sequence: (a) 3 February 2008; (b) 2 March 2009; and (c) 7 April 2014. The white inverted triangle shows a fixed point of reference at the base of a tree which appears in all the images.

\section{Discussion}

\subsection{Channel evolution and stability}

The changes observed in Glaisdale beck following channel reconfiguration were predicted beforehand (Warburton,

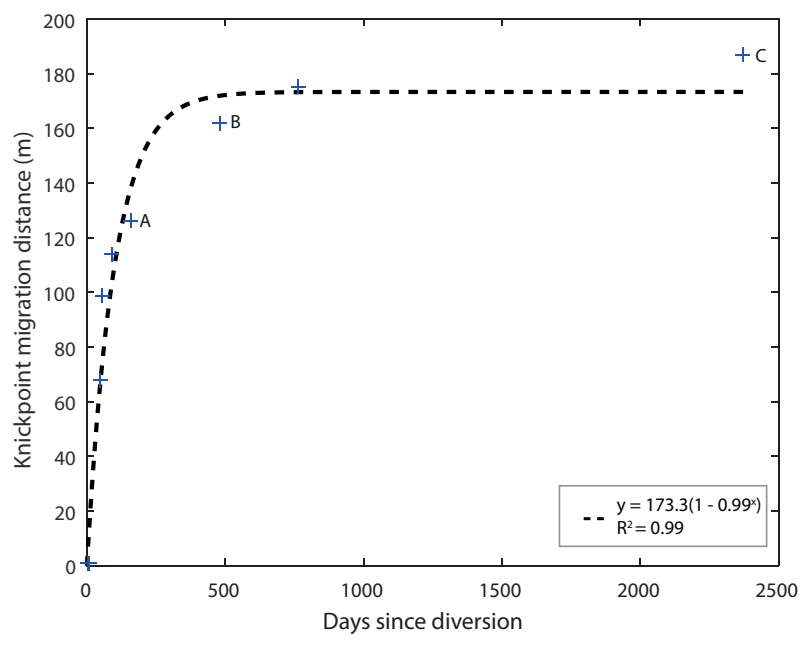

Figure 9. Plot between days since diversion and distance of headward knickpoint migration (m). Letters A-C correspond to the sequence of images in Fig. 8.

2007). It was anticipated that channel bed instability would result from the steepening of the newly aligned river channel and without appropriate engineering measures the channel would erode in a headward direction. However, lack of experience and appreciation of techniques for creating stable grade control structures, by the contractor and a dearth of suitable materials on-site resulted in the control measures becoming undermined. In the immediate vicinity of the channel diversion, rip rap successfully confined the stream to the desired location restricting the risk of lateral instability and channel migration. However, vertical down cutting, initially focused upstream of the grade control (drop) structures was triggered by local scouring which was exacerbated by steepening of the stream profile and the associated headward propagating knickpoint. The diversion of the channel resulted in a steepening of the local slope to a gradient close to $5 \%$ (Table 5), which shifted the channel into the range of slopes typical of step-pool streams (Chin et al., 2009). Under these conditions a new channel morphology needs to be considered and step-pools need to be considered as a suitable channel engineering structure. In this case study, a single large step was engineered to create the new channel morphology and ultimately this was unsuccessful and failed. Chin et al. (2009) list a set of important considerations relating to the design, construction and maintenance of step pool structures that should be followed when restoring high gradient channels. With the benefit of hindsight a staircase of multiple steps, constructed of large rock (imported to the site), spaced appropriately in the diversion reach would have been more effective in mitigating headward degradation (Chin et al., 2009). Overall however, the scheme effectively slowed the downslope movement of the large landslide complex which was destabilizing valuable farmland and contributing significant quantities of fine sediment to the beck. By disconnecting the 


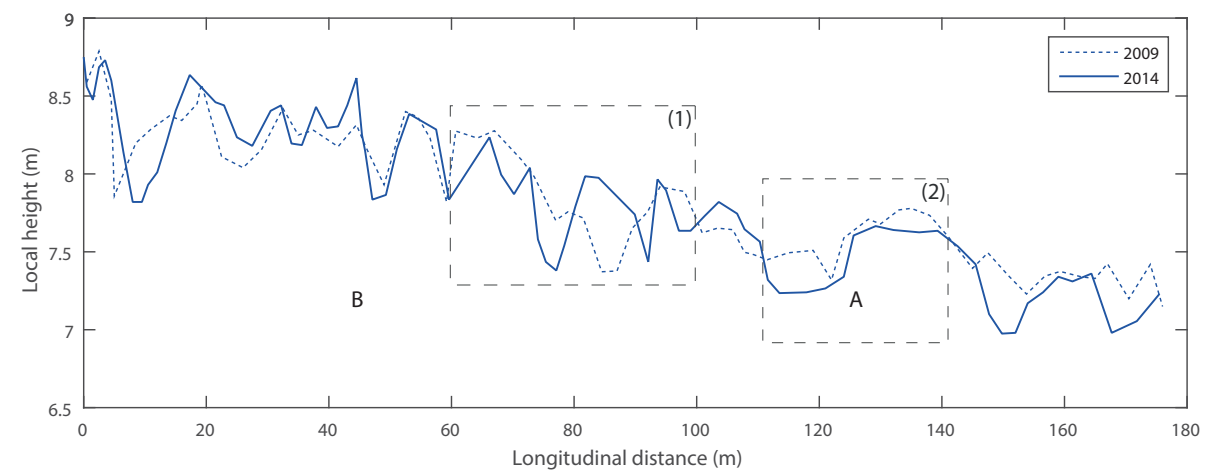

Figure 10. Comparison of long profile surveys of the channel diversion reach at Glaisdale Beck: 2 March 2009 to 7 April 2014. The dashed box labelled (1) shows the zone of lateral bank instability shown in Fig. 8. The dashed box labelled (2) represents the realigned section of the channel. (a) and (b) indicate the positions of the two main drop structures (weirs) on the river bed (locations also shown in Fig. 3).

river channel from the distal end of the landslide, and preventing over-steepening of the toe, the landslide crept into the old abandoned channel where movement was arrested.

\subsection{Channel realignment as river restoration}

Connectivity between potential sediment source areas and drainage networks in the uplands of the UK results in the mobilization and transfer of fine sediment from a range of point and diffuse sources across a catchment (e.g. Foster and Lees, 1999; Johnson et al., 2008). In order to identify areas of enhanced fine sediment transfer within the Esk catchment, research followed spatially nested-hierarchical principles (Brierley et al., 2010). This knowledge of sediment transfer processes enabled better understanding of the diversity and pattern of river character and behaviour across the catchment system. Areas within the catchment with atypical sediment dynamics compared with similar sub-catchments were identified. More focussed geomorphological surveys then identified key critical areas within the sub-catchment units. This process led to the identification of a specific reach along Glaisdale Beck as a key contributor to fine sediment loadings in the Esk catchment, prompting action from local authorities (Bracken and Warburton, 2005; Warburton, 2007). The authorities, primarily concerned by the potential loss of salmonid spawning and freshwater pearl mussel habitats following large quantities of fine sediment being mobilized by a progressive landslide and associated localized bank erosion, responded by consulting with local stakeholders over the available options before finally choosing to divert the river from the easily accessible sediment source. Inherent in this approach was the assumption that the risk to in-stream habitat was greater by doing nothing than by attempting to divert the channel away from the primary fine sediment pollution source. Due to the sensitivity of the site, it was agreed that in order to alleviate the problem effectively efforts should be directed towards a hard-engineering approach, which should minimize the potential risk of fail- ure. In the case of the channel realignment option, the channel was designed to be laterally stable with grade control measures in place (Warburton, 2007). This approach had the inherent potential to remove natural variability and heterogeneity in channel morphology, flow dynamics and available river habitats along the affected reach, whilst contradicting the popular movement from hard to soft engineering solutions (Hey, 1996; Richards, 2001; Raven et al., 2010; Newson, 2012). However, the clear identification of a manageable critical point source of fine sediment provided an opportunity to significantly reduce degradation of the system and to enhance the overall ecological integrity of the river beyond that of the reach scale (Palmer et al., 2005). Nevertheless as Wohl et al. (2015) suggest, reconfiguring channels is fraught with difficulty and often is only partially successful due to the local focus on the reach-scale. This case study, through long-term monitoring, has demonstrated this limitation but more importantly shown how the engineered reach, through longer-term natural adjustment, eventually reconnects with the larger river network to deliver large-scale benefits.

\section{Conclusions}

Glaisdale Beck was highlighted as experiencing elevated levels of fine sediment flux, with a significant source of this material being attributed to a large hillslope failure complex which was directly coupled to the channel. This reach was subject to a specific set of pressures which would result in traditional geotechnical stabilization techniques being inappropriate and ultimately unsuccessful. This offered the opportunity to trial the diversion of an upland channel, with the aim of reducing fine sediment flux, affording us the opportunity to gain a comprehensive understanding of the impacts of upland channel diversion on the fluvial sediment system. From the analysis of over 2 years discharge and SSC data prior to, and following the diversion of Glaisdale Beck, it is clear that the sediment transfer regime has become more restrictive as evidenced by 
- Reductions in median SSC from 35.19 to $18.98 \mathrm{mg} \mathrm{L}^{-1}$.

$-5 \%$ reduction in flow-weighted mean SSC.

- Negative trend in SSCs (Kendall's Tau; $p<0.001$ ).

- Development of sediment rating curves with statistically different coefficients following diversion. Both the $\log a$ and $b$ coefficients were smaller following the diversion.

- Decline in LOWESS residuals over time indicating an overestimation of SSCs as the channel stabilizes over time.

This monitoring campaign has indicated that prior to the diversion, Glaisdale Beck was experiencing enhanced fine sediment flux, with conditions unlikely to be favourable for salmonids or pearl mussel populations. Following channel diversion, a prolonged period of disturbance lasting approximately 7 years was observed. During this time, the channel and sediment regime are highly dynamic, with order of magnitude changes in fine sediment response occurring over short temporal scales. This is a result of disequilibrium in the fluvial sediment system following diversion with readjustment to the new channel configuration resulting in variations in the supply of fine-grained material. Despite this transient behaviour, there is evidence of non-stationarity in the fine sediment flux signal and it is anticipated that providing allogenic controls do not force further threshold changes, suspended sediment transfer will remain at lower levels than that of pre-diversion conditions, with a fine sediment transfer regime becoming established that is commensurate with the newly imposed conditions.

Although knickpoint migration has now nearly ceased, the channel is continuing to adjust to the threshold change, with evidence of continuing local instability. It is therefore recommended that this approach to reducing the fine sediment flux of upland rivers should not be adopted as standard practice. However, where significant modifications to upland channels are made, comprehensive in-stream monitoring and geomorphological assessments should be regularly conducted to evaluate the response of the river to the new conditions. This research has also highlighted the importance of ensuring appropriate controls on sediment release during in-stream works and effective installation and maintenance of grade control (drop) structures. If these measures had been rigorously applied the overall goal of reducing fine sediment flux through the fluvial system could have been achieved in a more timely fashion.

\section{Data availability}

Datasets produced and/or utilized in the production of this research article are publicly available at https://doi. pangaea.de/10.1594/PANGAEA.864201 (Perks and Warburton, 2016d). Datasets generated by this research are freely available for use provided attribution of the source is provided. MATLAB scripts used to produce Figs. 5-7 and 910 can be obtained at https://github.com/CatchmentSci/ Glaisdale-Beck-diversion-scheme (Perks, 2016).

Acknowledgements. The authors gratefully acknowledge the co-operation of local landowners for access to the field site and are thankful to the Environment Agency for providing access to river level data for the Lealholm monitoring station in the Esk catchment. Monitoring the impacts of the channel diversion was undertaken as part of the first authors $\mathrm{PhD}$ research project which was made possible following financial support from Durham University and the Environment Agency. We wish to thank Professor Ian Fuller and one anonymous reviewer whose comments significantly improved this manuscript. All views in the paper are those of the authors and should not be interpreted as necessarily representing the opinions of other land management agencies.

Edited by: G. Hancock

Reviewed by: I. Fuller and one anonymous referee

\section{References}

Angulo-Martínez, M., López-Vicente, M., Vicente-Serrano, S. M., and Beguería, S.: Mapping rainfall erosivity at a regional scale: a comparison of interpolation methods in the Ebro Basin (NE Spain), Hydrol. Earth Syst. Sci., 13, 1907-1920, doi:10.5194/hess-13-1907-2009, 2009.

Arnold-Forster, D.: Benefits to environment and economy through EU structural funds, with special reference to the North York Moors National Park, Joint Nature Conservation Committee, JNCC Report No. 319, in: The British Uplands: Dynamics of Change, edited by: Burt, T. P., Thompson, D. B. A., and Warburton, J., ISSN: 0963-8091, 83-90, 2002.

Asselman, N. E. M.: Fitting and interpretation of sediment rating curves, J. Hydrol., 234, 228-248, 2000.

Atherden, M.: Upland Britain: A Natural History, Manchester University Press, Manchester, 224 pp., 1992.

Bilotta, G. S., Krueger, T., Brazier, R. E., Butler, P., Freer, J., Hawkins, J. M. B., Haygarth, P. M., Macleod, C. J. A., and Quinton, J. N.: Assessing catchment-scale erosion and yields of suspended solids from improved temperate grassland, J. Environ. Monitor., 12, 731-739, 2010.

Bracken, L. and Warburton, J.: Monitoring fine sediment transfer in the River Esk, North York Moors, Northern England: Final Report, Durham University, 35, 2005.

Brierley, G., Reid, H., Fryirs, K., and Trahan, N.: What are we monitoring and why? Using geomorphic principles to frame ecohydrological assessments of river condition, Sci. Total Environ., 408, 2025-2033, doi:10.1016/j.scitotenv.2010.01.038, 2010.

British Geological Survey (BGS): Egton (Eskdale and Farndale) Sheet 43, 1:50000 Solid and drift edition, Geological Survey of England and Wales 1:63 360/1:50 000 geological map series, New Series, NERC, 1992.

Brookes, A.: River channel adjustments downstream from channelization works in England and Wales, Earth Surf. Proc. Land., 12, 337-351, doi:10.1002/esp.3290120402, 1987. 
Brown, A. G.: Biogeomorphology and Diversity in MultipleChannel River Systems, Global Ecol. Biogeogr., 6, 179-185, doi:10.2307/2997731, 1997.

Brown, L. C. and Foster, G. R.: Storm erosivity using idealized intensity distributions, Transactions of the American Society of Agricultural Engineers, 30, 379-386, 1987.

Bull, L. J.: Magnitude and variation in the contribution of bank erosion to the suspended sediment load of the River Severn, UK, Earth Surf. Proc. Land., 22, 1109-1123, doi:10.1002/(sici)10969837(199712)22:12<1109::aid-esp810>3.0.co;2-o, 1997.

Burt, T. P., Donohoe, M. A., and Vann, A. R.: The effect of forestry drainage operations on upland sediment yields: The results of a storm-based study, Earth Surf. Proc. Land., 8, 339-346, 1983.

Carling, P. A.: Deposition of fine and coarse sand in an open-work gravel bed, Can. J. Fish. Aquat. Sci., 41, 263-270, 1984.

Carling, P. A.: The Noon Hill flash floods; July 17th 1983. Hydrological and geomorphological aspects of a major formative event in an upland landscape, T. I. Brit. Geogr., 105-118, 1986.

Chin, A., Anderson, S., Collison, A., Ellis-Sugai, B., Haltiner, J., Hogervorst, J., Kondolf, G. M., O’Hirok, L., Purcell, A., Riley, A., and Wohl, E.: Linking Theory and Practice for Restoration of Step-Pool Streams, Environ. Manage., 43, 645-661, doi:10.1007/s00267-008-9171-x, 2009.

Cleveland, W. S.: Robust Locally Weighted Regression and Smoothing Scatterplots, J. Am. Stat. Assoc., 74, 829-836, doi:10.1080/01621459.1979.10481038, 1979.

Collins, A. L. and Anthony, S. G.: Assessing the likelihood of catchments across England and Wales meeting 'good ecological status' due to sediment contributions from agricultural sources, Environ. Sci. Policy, 11, 163-170, 10.1016/j.envsci.2007.07.008, 2008a.

Collins, A. L. and Anthony, S. G.: Predicting sediment inputs to aquatic ecosystems across England and Wales under current environmental conditions, Appl. Geogr., 28, 281-294, 2008b.

Collins, A. L. and McGonigle, D. F.: Monitoring and modelling diffuse pollution from agriculture for policy support: UK and European experience, Environ. Sci. Policy, 11, 97-101, doi:10.1016/j.envsci.2008.01.001, 2008.

Collins, A. L., Ohandja, D. G., Hoare, D., and Voulvoulis, N.: Implementing the Water Framework Directive: a transition from established monitoring networks in England and Wales, Environ. Sci. Policy, 17, 49-61, doi:10.1016/j.envsci.2011.11.003, 2012.

Cranston, M. D. and Black, A. R.: Flood warning and the use of weather radar in Scotland: a study of flood events in the Ruchill Water catchment, Meteorol. Appl., 13, 43-52, doi:10.1017/S1350482705001969, 2006.

DEFRA: The Natural Choice: Securing the value of Nature, London, UK, available at: https://www.gov.uk/government/uploads/ system/uploads/attachment_data/file/228842/8082.pdf (last access: 21 June 2016), 84 pp., Document No. CM 8082, 2011.

Doeg, T. and Milledge, G.: Effect of experimentally increasing concentration of suspended sediment on macroinvertebrate drift, Mar. Freshwater Res., 42, 519-526, doi:10.1071/MF9910519, 1991.

Duan, N.: Smearing Estimate: A Nonparametric Retransformation Method, J. Am. Stat. Assoc., 78, 605-610, 1983.

Elliott, R.: Faking Nature: The Ethics of Environmental Restoration, Routledge, London, 190 pp., 1997.
Emery, S. B.: In Better Fettle: Improvement, Work and Rhetoric in the Transition to Environmental Farming in the North York Moors, Doctoral Thesis, Durham Univeristy, UK, available at: http://etheses.dur.ac.uk/379/ (last access: 21 June 2016), 250 pp., 2010.

Emery, S. B., Perks, M. T., and Bracken, L. J.: Negotiating river restoration: The role of divergent reframing in environmental decision-making, Geoforum, 47, 167-177, doi:10.1016/j.geoforum.2013.01.008, 2013.

Environment Agency: River habitat quality: the physical character of rivers and stream in the UK and Isle of Man, edited by: Raven, P. J., Holmes, N. T. H., Dawson, F. H., Fox, P. J. A., Everard, M., Fozzard, I. R., Rouen, K. J., available at: http://www.riverhabitatsurvey.org/wp-content/uploads/2012/ 07/RHS.pdf (last access: 31 August 2016), Report No. 2, 86 pp., Environment Agency, Bristol, 1998.

Environment Agency: River Esk (Yorkshire) Tideway Byelaw Report Environment Agency, available at: http://www. northyorkmoors.org.uk/discover/rivers/reports-and-resources/ River-Esk-Tidal-Byelaw-Report-2011.pdf (last access: 17 July 2013), Environment Agency, 57 pp., 2011.

Environment Agency: Classification status and Objectives for WFD Cycle 1, Interim 2010, 2011, 2012, 2013, 2014 and 2015 data, available at: https://doi.pangaea.de/10.1594/PANGAEA.864201 (last access: 31 August 2016), 2015.

Evans, M. and Warburton, J.: Sediment budget for an eroding peat-moorland catchment in northern England, Earth Surf. Proc. Land., 30, 557-577, doi:10.1002/esp.1153, 2005.

Foley, J. A., DeFries, R., Asner, G. P., Barford, C., Bonan, G., Carpenter, S. R., Chapin, F. S., Coe, M. T., Daily, G. C., and Gibbs, H. K.: Global consequences of land use, Science, 309, 570-574, 2005.

Foster, I. D. L. and Lees, J. A.: Changing headwater suspended sediment yields in the LOIS catchments over the last century: a paleolimnological approach, Hydrol. Process., 13, 11371153, doi:10.1002/(SICI)1099-1085(199905)13:7<1137::AIDHYP794>3.0.CO;2-M, 1999.

Fuller, I. C., Large, A. R. G., Charlton, M. E., Heritage, G. L., and Milan, D. J.: Reach-scale sediment transfers: An evaluation of two morphological budgeting approaches, Earth Surf. Proc. Land., 28, 889-903, 2003.

Gao, P. and Josefson, M.: Temporal variations of suspended sediment transport in Oneida Creek watershed, central New York, J. Hydrol., 426-427, 17-27, doi:10.1016/j.jhydrol.2012.01.012, 2012.

Geist, J.: Conservation Genetics and Ecology of European Freshwater Pearl Mussels (Margaritifera margaritifera L.), PhD, Department für Ökosystem- und Landschaftsmanagement, Universität München, 132 pp., 2005.

Gilvear, D. and Bradley, S.: Geomorphological adjustment of a newly engineered upland sinuous gravel-bed river diversion: Evan Water, Scotland, Regul. Rivers, 13, 377389, doi:10.1002/(SICI)1099-1646(199707)13:4<377::AID RRR463>3.0.CO;2-4, 1997.

Gippel, C. J.: Potential of turbidity monitoring for measuring the transport of suspended solids in streams, Hydrol. Process., 9, 8397, 1995

Gray, J. R., Glysson, G. D., and Mueller, D. S.: Comparability and accuracy of fluvial seidment data - a view from the U.S. Geologi- 
cal Survey, Speciality Conference, Hydraulic Measurements and Experimental Methods, Colorado, USA, 28 July-1 August 2002.

Helsel, D. R. and Hirsch, R. M.: Statistical Methods in Water Resources, Elsevier, Amsterdam, the Netherlands, 522 pp., 1992.

Hey, R. D.: Environmentally sensitive river engineering, in: River restoration, edited by: Petts, G. E. and Calow, P., Blackwell Science Ltd, Oxford, 80-105, 1996.

Hicks, D. M., Gomez, B., and Trustman, N. A.: Erosion thresholds and suspended sediment yields, Waipaoa River Basin, New Zealand, Water Resour. Res., 36, 1129-1142, 2000.

Holden, J., Palmer, S. M., Johnston, K., Wearing, C., Irvine, B., and Brown, L. E.: Impact of prescribed burning on blanket peat hydrology, Water Resour. Res., 51, 6472-6484, doi:10.1002/2014WR016782, 2015.

Imeson, A. C.: Heather Burning and Soil Erosion on the North Yorkshire Moors, J. Appl. Ecol., 8, 537-542, 1971.

Johnson, R. M., Warburton, J., and Mills, A. J.: Hillslope-channel sediment transfer in a slope failure event: Wet Swine Gill, Lake District, northern England, Earth Surf. Proc. Land., 33, 394-413, doi:10.1002/esp.1563, 2008.

Lawler, D. M.: The measurement of river bank erosion and lateral channel change: A review, Earth Surf. Proc. Land., 18, 777-821, doi:10.1002/esp.3290180905, 1993.

Lawler, D. M., Couperthwaite, J., Bull, L. J., and Harris, N. M.: Bank erosion events and processes in the Upper Severn basin, Hydrol. Earth Syst. Sci., 1, 523-534, doi:10.5194/hess-1-5231997, 1997.

Machordom, A., Araujo, R., Erpenbeck, D., and Ramos, M.-Á.: Phylogeography and conservation genetics of endangered European Margaritiferidae (Bivalvia: Unionoidea), Biol. J. Linn. Soc., 78, 235-252, doi:10.1046/j.1095-8312.2003.00158.x, 2003.

Macklin, M. G., Hudson-Edwards, K. A., and Dawson, E. J.: The significance of pollution from historic metal mining in the Pennine orefields on river sediment contaminant fluxes to the North Sea, Sci. Total Environ., 194-195, 391-397, doi:10.1016/S00489697(96)05378-8, 1997.

Marshall, M. R., Francis, O. J., Frogbrook, Z. L., Jackson, B. M., McIntyre, N., Reynolds, B., Solloway, I., Wheater, H. S., and Chell, J.: The impact of upland land management on flooding: results from an improved pasture hillslope, Hydrol. Process., 23, 464-475, doi:10.1002/hyp.7157, 2009.

McHugh, M.: Short-term changes in upland soil erosion in England and Wales: 1999 to 2002, Geomorphology, 86, 204-213, 2007.

Meusburger, K., Steel, A., Panagos, P., Montanarella, L., and Alewell, C.: Spatial and temporal variability of rainfall erosivity factor for Switzerland, Hydrol. Earth Syst. Sci., 16, 167-177, doi:10.5194/hess-16-167-2012, 2012.

Newson, M. D.: Geomorphological concepts and tools for sustainable river ecosystem management, Aquat. Conserv., 12, 365379, doi:10.1002/aqc.532, 2002.

Newson, M. D. and Large, A. R. G.: 'Natural' rivers, 'hydromorphological quality' and river restoration: a challenging new agenda for applied fluvial geomorphology, Earth Surf. Proc. Land., 31, 1606-1624, doi:10.1002/esp.1430, 2006.

Newson, M. D.: From Channel to Catchment: A 20-Year Journey for River Management in England and Wales, in: River Conservation and Management, edited by: Boon, P. J. and Raven, P. J., John Wiley \& Sons, Ltd, Chichester, UK, 15-27, doi:10.1002/9781119961819.ch2, 2012.
Owens, P. N., Batalla, R. J., Collins, A. J., Gomez, B., Hicks, D. M., Horowitz, A. J., Kondolf, G. M., Marden, M., Page, M. J., Peacock, D. H., Petticrew, E. L., Salomons, W., and Trustrum, N. A.: Fine-grained sediment in river systems: environmental significance and management issues, River Res. Appl., 21, 693-717, doi:10.1002/rra.878, 2005.

Palmer, M. A., Bernhardt, E. S., Allan, J. D., Lake, P. S., Alexander, G., Brooks, S., Carr, J., Clayton, S., Dahm, C. N., Follstad Shah, J., Galat, D. L., Loss, S. G., Goodwin, P., Hart, D. D., Hassett, B., Jenkinson, R., Kondolf, G. M., Lave, R., Meyer, J. L., O'Donnell, T. K., Pagano, L., and Sudduth, E.: Standards for ecologically successful river restoration, J. Appl. Ecol., 42, 208-217, 10.1111/j.1365-2664.2005.01004.x, 2005.

Perks, M. T.: Glaisdale-Beck-diversion-scheme, GitHub repository, available at: https://github.com/CatchmentSci/ Glaisdale-Beck-diversion-scheme, 2016.

Perks, M. and Warburton, J.: River discharge and suspended sediment concentrations measured at Glasdale Beck (2007-09), Dataset \#864198, available at: https://doi.pangaea.de/10.1594/ PANGAEA.864198, 2016a.

Perks, M. and Warburton, J.: Knickpoint migration between 2007-14 following the channel diversion of Glaisdale Beck, Dataset \#864159, available at: https://doi.pangaea.de/10.1594/ PANGAEA.864159, 2016b.

Perks, M. and Warburton, J.: Longitudinal change in thalweg elevation between 2009-14 in response to the channel diversion of Glaisdale Beck, Dataset \#864160, available at: https://doi. pangaea.de/10.1594/PANGAEA.864160, 2016c.

Perks, M., and Warburton, J.: Glaisdale Beck diversion scheme - channel change and suspended sediment response, Dataset \#864201, available at: https: //doi.pangaea.de/10.1594/PANGAEA.864201, 2016d.

Perks, M. and Warburton, J.: Met Office Rain Radar Data from the NIMROD System, NCAS British Atmospheric Data Centre, Dataset \#864200, available at: https://doi.pangaea.de/10.1594/ PANGAEA.864200, 2016e.

Perks, M. and Warburton, J.: River levels for the River Esk at Lealholm (1998-2016), Dataset \#864199, Environment Agency, GOV. UK, available at: https://doi.pangaea.de/10.1594/ PANGAEA.864199, 2016f.

Perks, M. T., Warburton, J., and Bracken, L.: Critical assessment and validation of a time-integrating fluvial suspended sediment sampler, Hydrol. Process., 28, 4795-4807, doi:10.1002/hyp.9985, 2014.

Posthumus, H., Deeks, L. K., Rickson, R. J., and Quinton, J. N.: Costs and benefits of erosion control measures in the UK, Soil Use and Management, 31, 16-33, doi:10.1111/sum.12057, 2013.

Ramchunder, S. J., Brown, L. E., and Holden, J.: Environmental effects of drainage, drain-blocking and prescribed vegetation burning in UK upland peatlands, Prog. Phys. Geog., 33, 49-79, doi:10.1177/0309133309105245, 2009.

Raven, E. K., Lane, S. N., and Bracken, L. J.: Understanding sediment transfer and morphological change for managing upland gravel-bed rivers, Prog. Phys. Geog., 34, 23-45, doi:10.1177/0309133309355631, 2010.

Reid, I. and Frostick, L. E.: Discussion of conceptual models of sediment transport in streams, in: Sediment Transport in GravelBed Rivers, edited by: Thorne, C. R., Bathurst, J. C., and Hey, R. D., John Wiley \& Sons, Chichester, UK, 410-411, 1987. 
Richards, K. S.: Floods, channel dynamics and riparian ecosystems in: Gravel bed rivers V, edited by: Mosley, P. M., Hydrological Society, Wellington, New Zealand, 465-478, 2001.

Rickson, R. J.: Can control of soil erosion mitigate water pollution by sediments?, Sci. Total Environ., 468-469, 1187-1197, doi:10.1016/j.scitotenv.2013.05.057, 2014.

Robertson, M. J., Scruton, D. A., and Clarke, K. D.: Seasonal Effects of Suspended Sediment on the Behavior of Juvenile Atlantic Salmon, T. Am. Fish. Soc., 136, 822-828, doi:10.1577/t06164.1, 2007.

Robinson, A. R.: Sediment, our greatest pollutant, in: Focus on environmental geology; Geologic Hazards and hostile environments; Erosion sedimentation and floods, edited by: Tank, R., Oxford University Press, London, 186-192, 1973.

Rosenberg, D. M. and Wiens, A. P.: Effects of sediment addition on macrobenthic invertebrates in a Northern Canadian River, Water Res., 12, 753-763, 1978.

Schumm, S. A.: The fluvial system, Wiley, New York, USA, 338 pp., 1977.

Sear, D. and Archer, D. R.: The effects of gravel extraction on the stability of gravel-bed rivers: A case study from the Wooler Water, Northumberland, UK, in: Gravel bed rivers in the environment, edited by: Klingeman, P., Beschta, R. L., Komar, B. D., and Milhous, R. T., Water Res. Counci, Colorado, USA, 415432, 1998.

Sear, D., Wilcock, D. N., Robinson, M., and Fisher, K.: River channel modification in the UK, in: The hydrology of the UK: A study of change, edited by: Acreman, M., Routledge, London, 55-81, 2000.

Sear, D., Newson, M., Hill, C., Old, J., and Branson, J.: A method for applying fluvial geomorphology in support of catchmentscale river restoration planning, Aquat. Conserv., 19, 506-519, doi:10.1002/aqc.1022, 2009.

Sheridan, G. J., Lane, P. N. J., Sherwin, C. B., and Noske, P. J.: Post-fire changes in sediment rating curves in a wet Eucalyptus forest in SE Australia, J. Hydrol., 409, 183-195, doi:10.1016/j.jhydrol.2011.08.016, 2011.

Skinner, A., Young, M., and Hastie, L.: Ecology of the freshwater pearl mussel, English Nature, Peterborough, available at: http: //publications.naturalengland.org.uk/file/121017, 20, 2003.

Skinner, K. S. and Bruce-Burgess, L.: Strategic and project level river restoration protocols - key components for meeting the requirements of the Water Framework Directive (WFD), Water Environ. J., 19, 135-142, doi:10.1111/j.1747-6593.2005.tb00561.x, 2005.
Stott, T.: A comparison of stream bank erosion processes on forested and moorland streams in the Balquhidder Catchments, central Scotland, Earth Surf. Proc. Land., 22, 383399, doi:10.1002/(SICI)1096-9837(199704)22:4<383::AIDESP695>3.0.CO;2-4, 1997.

Stutter, M. I., Langan, S. J., and Cooper, R. J.: Spatial and temporal dynamics of stream water particulate and dissolved N, P and C forms along a catchment transect, NE Scotland, J. Hydrol., 350, 187-202, 2008.

Syvitski, J. P. M., Morehead, M. D., Bahr, D. B., and Mulder, T.: Estimating fluvial sediment transport: The rating parameters, Water Resour. Res., 39, 2747-2760, 2000.

Tilman, D., Cassman, K. G., Matson, P. A., Naylor, R., and Polasky, S.: Agricultural sustainability and intensive production practices, Nature, 418, 671-677, 2002.

Waltham, T. and Forster, A.: Man as geological agent, Geology Today, 15, 217-220, doi:10.1046/j.1365-2451.1999.00005.x, 1999.

Warburton, J.: Glaisdale Beck Diversion Review, Private Consultancy Report, Durham University, 16 pp., July 2007.

Warrick, J. A. and Rubin, D. M.: Suspended-sediment rating curve response to urbanization and wildfire, Santa Ana River, California, J. Geophys. Res., 112, F02018, doi:10.1029/2006JF000662, 2007.

Warrick, J. A.: Trend analyses with river sediment rating curves, Hydrol. Process., 29, 936-949, doi:10.1002/hyp.10198, 2015.

Wilkinson, M. E., Quinn, P. F., Barber, N. J., and Jonczyk, J.: A framework for managing runoff and pollution in the rural landscape using a Catchment Systems Engineering approach, Sci. Total Environ., 468-469, 1245-1254, doi:10.1016/j.scitotenv.2013.07.055, 2013.

Wohl, E., Lane, S. N., and Wilcox, A. C.: The science and practice of river restoration, Water Resour. Res., 51, 5974-5997, doi:10.1002/2014WR016874, 2015.

Wolman, M. G. and Miller, W. P.: Magnitude and frequency of forces in geomorphic processes, J. Geol., 68, 54-74, 1960.

Wood, P. A.: Controls of variation in suspended sediment concentration in the River Rother, West Sussex, England, Sedimentology, 24, 437-445, 1977.

Yang, G., Chen, Z., Yu, F., Wang, Z., Zhao, Y., and Wang, Z.: Sediment rating parameters and their implications: Yangtze River, China, Geomorphology, 85, 166-175, doi:10.1016/j.geomorph.2006.03.016, 2007.

Zhu, D., Xuan, Y., and Cluckie, I.: Hydrological appraisal of operational weather radar rainfall estimates in the context of different modelling structures, Hydrol. Earth Syst. Sci., 18, 257-272, doi:10.5194/hess-18-257-2014, 2014. 